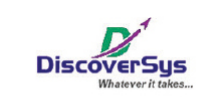

Published by DiscoverSys

\section{Quality analysis of quality control system in work units based on the Routine Data Quality Assessment of X Hospital in Semarang District}

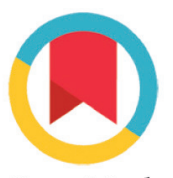

CrossMark

\author{
Endang Fatmawati, ${ }^{1}$ Farid Agushybana, ${ }^{2 *}$ Septo Pawelas Arso ${ }^{2}$
}

\section{ABSTRACT}

Background and purpose: An excellent process of hospital quality management system produces useful data for the management in the future decision-making. The problem obtained from the quality management system of $X$ hospital was that the data collectors do not understand the procedure of data collection, thus the data became less complete and less accurate. Routine Data Quality Assessment (RDQA) instrument is recommended to measure the data quality. This study aims to analyze the data quality in the quality management system of X Hospital work unit in Semarang. Methods: Quantitative method was applied in this study using cross-sectional approach. RDQA instrument was used as a model of quality assessment of routine data that can be implemented to evaluate the quality of the collected data. Purposive sampling was used in the selection of informants. This study involved 22 quality managers at level I (the wards) as the informants who conducted the data selection, three quality managers at level II as data collectors, and one quality manager at level III as a data center. The data were analyzed both quantitatively and qualitatively. The work units assessed in this study include the outpatient, inpatient and critical units.

Result: RDQA instrument was adapted by adjusting the substance of RDQA with the standards of hospital accreditation in Indonesia. The development of indicator 2 focused on the understanding of data collection, while indicator 3 focused on the supervision of data collection, and indicator 5 focused on the staff understanding on the recommendation of quality achievement results. The application of RDQA articulated that the quality control systems did not optimally run, including the lack of understanding of the data collection procedure, non optimal supervision of quality management, not all quality manager conduct data verification properly, not all staff understand the recommendations of the quality achievement results. The highest percentage of the data quality was $93 \%$ and the lowest was $72 \%$. In general, the system assessment was 1.5-2.5 which indicated that the data were partially complete/available/ operated.

Conclusion: RDQA resulted that the data quality control on the hospital quality management system has not yet to be conducted optimally.

Keywords: quality, RDQA, quality management system

Cite this Article: Fatmawati, E., Agushybana, F., Arso, S.P. 2020. Quality analysis of quality control system in work units based on the Routine Data Quality Assessment of X Hospital in Semarang District. Public Health and Preventive Medicine Archive 8(2): 92-98.

DOI: 10.15562/phpma.v8i2.302

${ }^{1}$ Dr Kariadi General Hospital, Semarang, Indonesia ${ }^{2}$ Master of Public Health, Faculty of Public Health, Diponegoro University, Semarang, Indonesia

*Correspondence to: Farid Agushybana; Master of Public Health, Faculty of Public Health, Diponegoro University, Semarang, Indonesia; agushybana@gmail.com

\section{INTRODUCTION}

Changes on the health care management encourage hospitals to prepare advancement measures in order to improve the quality and ensure patient safety. ${ }^{1}$ Quality program is developed in a planned, targeted, intensive, effective and efficient way to bring an impact on the improvement of all aspects of the health services. A study conducted by Braithwaite et al. (2020) showed that all hospital managers developed systems as the strategy for performance monitoring, incidents recording and reporting. The study found that the developed system did not show any indication of better success in the provision of health services. ${ }^{2}$ The success of hospital quality management in Indonesia is manifested by the success of the hospital accreditation implementation. However, most hospitals require great effort in the preparation process, and it shows that the quality activities have yet to be the culture of the day to day work. X Hospital in Semarang is a vertical referral hospital that provides complex sub-specialist services. X Hospital establishes a system of quality management as the monitoring and evaluation measures in the implementation of health services.

The measures of quality improvement are managed using a quality management system. The developed system produces data as an information for the management in evaluating the program. Accurate data are valuable information and affect the accuracy in decision-making. Quality management system is developed with 3 (three) levels of quality manager. Each level has continuous role in the quality improvement. The first level plays a role as the first key of success in data collection to obtain accurate data. The second level is the installation or the work unit as the second key of 
success, with a job of collecting data from the first level and conducting data verification. The third level is Planning and Evaluation (PE) Department as a data center. ${ }^{3}$

Management evaluates the services directly with management round. Chief of management directly observes the implementation of the quality management system and it was found to be not in accordance with the information or data of the reported achievements results. The results of the evaluation of quality management showed that there were errors in recording, errors in transcription, errors in sampling, errors in inputing the data and incomplete data report. Improvement measures were prepared by the Committee of Quality and Patient Safety by organizing workshop in June 2019 for 755 data collector officers in X Hospital. ${ }^{3}$ Participants brought their own guidelines of data collection that become their responsibility. Comprehensively, identifying the understanding of the staffs in collecting the data. The results of the workshop showed that $2.9 \%$ of 755 participants understand the procedure of data collection properly. It became the foundation for the management to improve the quality management system by optimizing the tiered supervision for the quality manager.

Management ensures the accuracy of data quality using the data validation. However, data validation could only detect the accuracy of the achievement results, and was not used to assess the quality management system. ${ }^{3}$ Assessment of the data quality can be conducted using Routine Data Quality Assessment (RDQA) instrument. Previous studies on the data quality recommended RDQA to be used as an assessment instrument. ${ }^{4}$ RDQA is an instrument of data quality assessment developed by UNICEF. RDQA is used by the World Health Organization (WHO) for monitoring the quality of data on tuberculosis (TB) in the national program "Stop TB". RDQA instrument can be used to assess the accuracy of the data and assess the quality management system. ${ }^{5}$ RDQA instruments can also identify the weaknesses in the quality management. RDQA is also equipped with a table of assessment review that can be automatically interpreted according to the category of assessment. Therefore, the researchers were interested in conducting a study using RDQA instrument in X hospital. This study aims to analyze the data quality in the unit of quality management system of $\mathrm{X}$ Hospital in Semarang.

\section{METHODS}

This study was conducted in $\mathrm{X}$ Hospital in Semarang. It is worth noting that $\mathrm{X}$ Hospital holds a role as the national referral hospital. It has 1,039 bed capacity with 4,654 staffs. Currently, X Hospital has 4 featured services, including the integrated cardiac services, integrated oncology, organs transplant, and minimally invasive surgery service. The average number of inpatients is 800 patients per day, and outpatient visits is 1,500 people per day.

Informants from three levels of quality management system in X Hospital were involved in this study. The first level consists of 22 people (16 persons in charge (PIC) of the data and six head of divisions). For the 16 people who select the data (PIC of the data), three of them were selected from critical unit, another six from inpatient unit and six others from outpatient unit. In addition to the PIC of the quality data, there were six head of divisions with an important role as the quality manager in the first level. The head of division consisted of two head of divisions of critical unit (the ICU ward and the HCU ward), where the head of the ICU ward became the PIC of the data at the same time; two head of divisions of inpatient unit, Ward A and Ward B; and two heads of divisions of outpatient unit, Merpati Ward at ground floor and Merpati Ward at first floor. The head of divisions were responsible to conduct monitoring and evaluation of the data collection carried out by the PIC of the quality data.

The second level quality manager comprised of three PIC of work unit quality. One of them was responsible for the quality of intensive care unit, another one was responsible for the quality of inpatient unit, and the last one was responsible for the quality of outpatient unit. The second level quality manager held a responsibility as the collector of medium data. Quality data delivered by the head of divisions on the first level were collected, recorded, verified and analyzed before being recommended.

The third level quality manager consisted of one head of sub-division of the evaluation in the data center division. The quality manager in the third level held responsibilities to collect the central data derived from the second level, and to verify the collected data. Purposive sampling was used to select samples of the present study.

Quantitative research method using crosssectional approach was applied in this study. RDQA instrument was used, which is a model of quality assessment of routine data that can be implemented to evaluate the quality of the collected data. RDQA instrument consists of data verification and system evaluation. First, the data verification is applied to confirm the accuracy of data that includes review of the document, report of the calculation results and validation of the report results with the data source. The second assessment system is collecting evidence 
to obtain the characteristics of staffs in carrying out the duties which consists of five indicators: (1) structure, functions and capabilities of monitoring and evaluation (M\&E): ensure the quality managers understand their duties, (2) guidelines of data collection and reporting: examine the availability of guidelines, (3) collection of reporting data and tools: ensure the standard of the applied format, (4) data management processes: ensure the availability of monitoring of the data quality, (5) dissemination of the report results: ensure a further management of the quality achievements results.

RDQA instrument is equipped with a table of assessment review of the data management and reporting system. Assessment score will be automatically filled in the table and the color changes according to the category. Score of $<1.5$ is the red category which represents the data that are not complete or not available or not operated. Score of $1.5-2.5$ is the yellow category which implies that the data are partially (complete/available/ operated). Score of 2.5 - 3.0 is the green category which indicates that the data are complete/available/ operated. The final result automatically presents the means of assessment.

The indicators assessed in this study are indicator 2,3 and 5 . The details of those indicators are described as follows; indicator 2 is the guidelines in selecting the data and reporting: identify the staff's understanding on the data collection; indicator 3 is the collection of reporting data and tools: identify the activities of quality managers in conducting supervision; and indicator 5 is dissemination of the report results: identify the activities of returning information on the quality achievement results to the staffs. The first RDQA component is in accordance with the quality improvement programs of the hospital. The development formulated on the indicator 2 (guidelines in collecting the data and reporting) emphasized on the understanding of data collection based on the indicator profile as a guide of data collection on the quality management system of X Hospital to improve the reporting quality. The development was made on the following question items: (1) Is there a profile of quality indicator, (2) Do the officers understand the profile of quality indicator, (3) How are the flow of reporting, to whom the reports should be sent, and (4) When is the report submitted.

Development on indicator 3 (collection of reporting data and tool) emphasized in assisting the quality manager of those in the lower level during the data collection, which aimed to improve the reporting quality. Development was implemented on the following question items: (1) data collection was in accordance with the profile of indicators,
(2) data collection on the source documents had been quite accurate to measure the indicators, (3) standard reporting instruments/forms were used consistently, (4) relevant source documents and reporting forms, and conduct a supervision

The development of indicator 5 (dissemination of the results of the report) emphasized on the efforts of the quality manager in providing information on the results of achievement to those in the lower level as a measure for the further improvement. The development was applied on the following question items: (1) dissemination schedule, (2) materials of dissemination are relevant at each level, (3) there is an invitation of attendance notes, (4) the officers understand the follow-up plan of dissemination results.

In this study, RDQA instrument was adapted to adjust the substance of RDQA with the standards of hospital accreditation in Indonesia. RDQA instrument was developed based on the hospital accreditation standards. The researchers along with the chairman of the committee on the quality, the quality team, and the accreditation team conducted a brainstorming. This development also involved the assessment team that helped the researchers in collecting research data, thus possessed a good understanding of the RDQA instrument. The result of the RDQA instrument development was used to assess the quality of the quality management system based on the hospital accreditation standards, on the standards of quality improvement and patient safety (Peningkatan Mutu dan Keselamatan Pasien (PMKP)).

PMKP 2.1, PMKP 3, PMKP 4 and PMKP 8 standards mention that in managing the quality data, the hospital needs a support from the information technology which includes the collection, report, analysis, validation and publication of the data for hospital's internal and external parties. Quality training needs to be provided for the quality manager to ensure the understanding in data collection. PMKP 7, PMKP 7.1 and PMKP 11 mention that in managing the data, a supervision, analysis and management need to be conducted using data management system which includes the collection, report, analysis, feedback and publication.

In addition, structured interview was applied as the data collection method in this study toward the quality manager of the quality management system as the subjects of the study. A list of questions adopted from the developed interview guide of RDQA instrument was used by the researchers. The interview guide contained 32 questions at level 1 and level 2, and 33 questions at level 3.

Quantitative method was used for the analysis technique in the present study. Quantitative 
method is presented in a form of spider chart and bar graph, and the graph shows the output of RDQA application. ${ }^{7}$ Spider chart presents the qualitative data of the conclusion of the assessment system. The higher the achievement score, the higher the performance of the system. Low achievement is used for a priority of improvement area. Bar graph depicts the quantitative data containing the conclusion of the data verification. The higher the bar, the higher the accuracy of the data. This achievement is used to plan the improvement of the data quality.

\section{RESULTS}

The assessment of data quality using the data of quality achievement was conducted in November 2019. The data were obtained from the measurement results of the indicator on the monitoring of accuracy in the completion of informed consent forms, indicator on the monitoring of accuracy in the supervision of doctor in charge (Dokter Penanggung Jawab Pasien (DPJP)) to the students of Specialist Doctor Education Program (Program Pendidikan Dokter Spesialis (PPDS)), and indicator on the monitoring of accuracy in the maintenance and calibration of medical equipment. There were no constraints in the application of the instrument because the instrument had been developed according to the quality program requirements in the hospital.

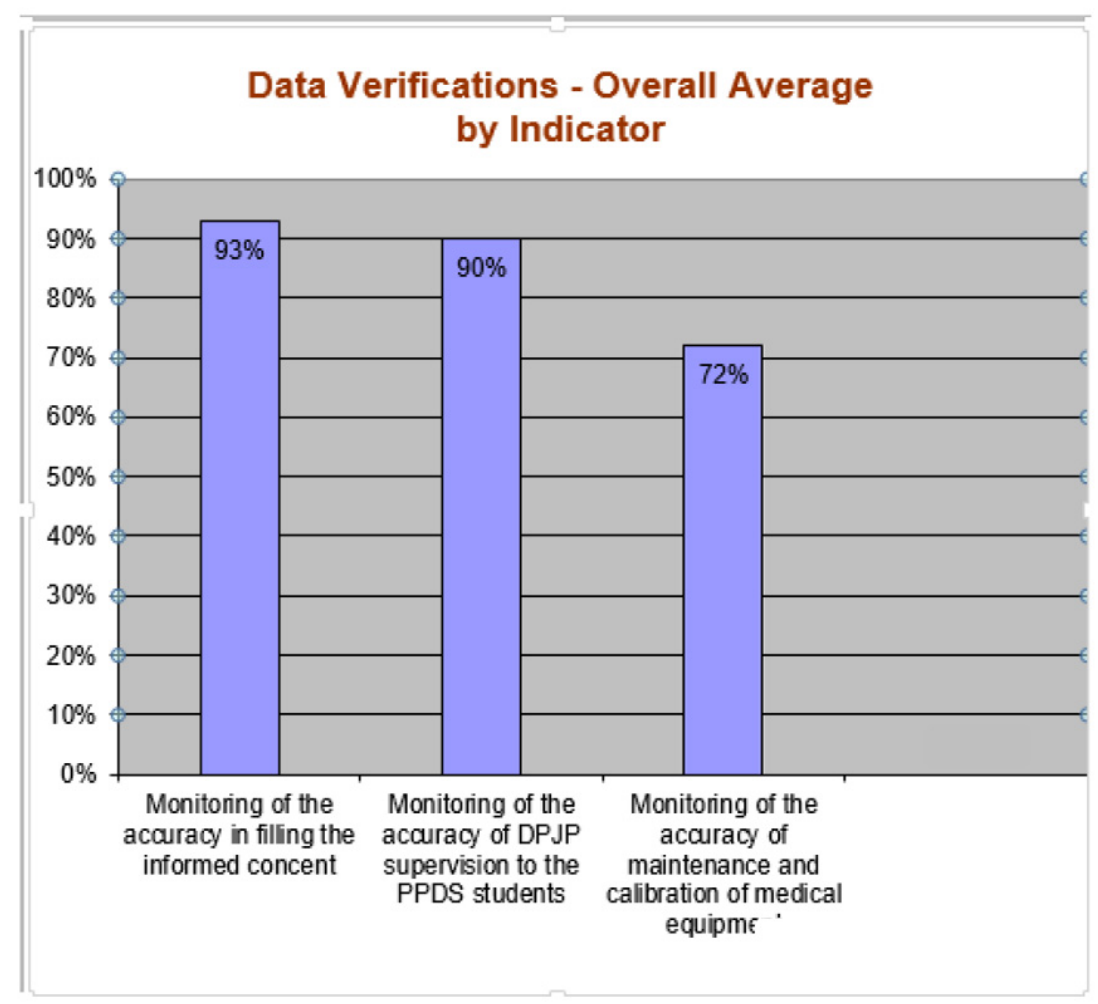

Figure 1. Global statistic of the dashboard of the data quality in the work unit management system

\section{Quantitative Approach}

Figure 1 and 2 show the highest achievement of the data is in the first indicator, the compliance in completing the informed consent forms (83\%). The lowest achievement of the data is in the third indicator, maintenance of medical equipment calibration (72\%). The three data obtained have yet to reach $100 \%$. It showed that the data accuracy was not optimal. The data with the lowest results were used to improve data management. From the obtained results, several were found to be different from the guidelines of data collection. It happened because the manager perceived that managing the data manually was difficult, thus resulting in the duplicate data.

\section{Data Management Quality}

The result of the data management assessment and the assessment system is presented in a form of table of the data management assessment and the assessment system review.

On the system assessment, around $60 \%$ were included in the green category and $40 \%$ others in the yellow category. The average assessment of the overall level of quality management system on the indicator 4, the process of data management, was in the yellow category with the mean of 1.93 . On the indicator 5, the dissemination of report results, a mean of 2,34 was obtained that made it included in the yellow category, and the second level (outpatient unit) indicated that the lowest quality was in the score of 1.25 , and included in the red category. The overall assessment of the system was in the yellow category with a score of 1.5-2.5 which indicated that the data were partially complete/available/operated.

\section{DISCUSSION}

On the development of RDQA instrument in indicator 2 (guidelines in selecting the data and reporting), this study found that the understanding on the data collection based on the guidelines of data collection is crucial. It aims to make the data on the achievement results to be a real information for the stakeholders for further decision-making purposes. This finding is in line with the findings of a study conducted by Sari (2014) that an understanding of the standard and utilization of system significantly affects the report quality. ${ }^{7}$ Similarly, a study conducted by Sri (2019) found that the knowledge of the coder on the codification of the disease diagnosis is the factor that contributes the most in the accuracy of codefication of the disease diagnosis. ${ }^{8}$

On the development of indicator 3 (collection of reporting data and tools), it was found that quality manager assistance to those in the lower level in 


\section{Data Management Assessment - Sistem Manajemen Mutu}

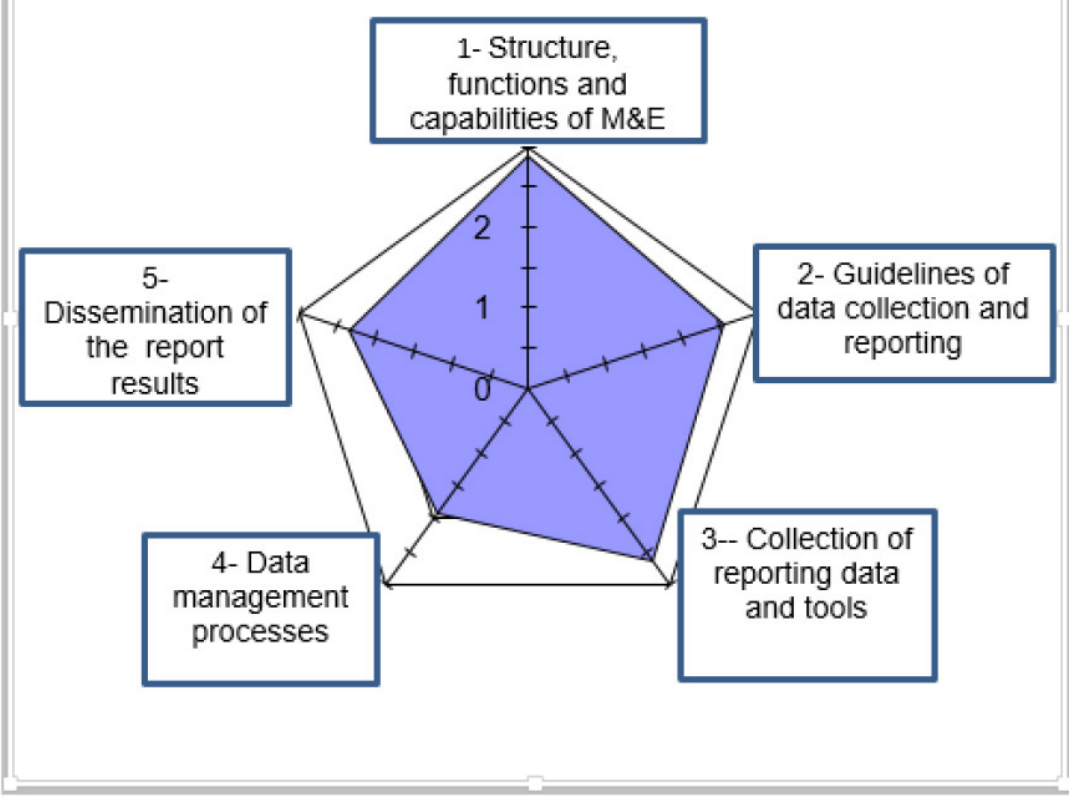

Figure 2. Global Dashboard of System Assessment

the data collection is crucial with the objective of improving the quality of the data. This finding is in accordance with the study conducted by Sulistia (2018) that monitoring and evaluation significantly affect the quality of reporting. ${ }^{9}$

In the development of indicator 5 (dissemination of the report results), it was found that the efforts

Table 1. Review of data management assessment and the assessment system

\begin{tabular}{|c|c|c|c|c|c|c|}
\hline \multirow{2}{*}{ Assessment } & \multicolumn{5}{|c|}{ Indicators (per function) } & \multirow{2}{*}{$\begin{array}{c}\text { Means per } \\
\text { level }\end{array}$} \\
\hline & 1 & 2 & 3 & 4 & 5 & \\
\hline \multicolumn{7}{|c|}{ Third Level } \\
\hline $\mathrm{PE}$ & 3.00 & 3.00 & 2.75 & 1.78 & 3.00 & 2.71 \\
\hline \multicolumn{7}{|c|}{ Second Level } \\
\hline Critical Unit & 3.00 & 3.00 & 2.75 & 2.00 & 2.50 & 2.65 \\
\hline Inpatient Unit & 3.00 & 3.00 & 3.00 & 2.00 & 2.25 & 2.65 \\
\hline Outpatient Unit & 2.65 & 2.25 & 1.75 & 1.56 & 1.25 & 1.90 \\
\hline \multicolumn{7}{|c|}{ First Level } \\
\hline ICU & 3.00 & 3.00 & 3.00 & 2.00 & 2.50 & 2.70 \\
\hline $\mathrm{HCU}$ & 3.00 & 2.75 & 2.80 & 2.00 & 2.50 & 2.61 \\
\hline Ward A & 3.00 & 2.25 & 3.00 & 1.83 & 2.75 & 2.57 \\
\hline Ward B & 3.00 & 2.00 & 3.00 & 2.00 & 2.50 & 2.50 \\
\hline Merpati ground floor & 3.00 & 3.00 & 3.00 & 2.00 & 2.00 & 2.60 \\
\hline Merpati 1st floor & 2.00 & 1.50 & 2.80 & 2.00 & 2.00 & 2.06 \\
\hline Average per function & 2.88 & 2.60 & 2.78 & 1.93 & 2.34 & 2.51 \\
\hline
\end{tabular}

of the quality manager in providing information on the results of achievement to those in the lower level was a measure for the further improvement. It is in line with a study conducted by Rodiah (2018) that the success of dissemination is affected by the ability to analyze the target, and it includes identifying objectives, information needs and the implemented procedures. ${ }^{10}$

This study found that quality manager is lacking an understanding on the guidelines of data collection and reporting, and have yet to conduct a supervision and provide feedback of the result of achievement optimally. As the staffs were not able to obtain adequate information about the measures of quality improvement. This study resulted in the ability to identify weaknesses in the quality management system. This finding is in line with a study conducted by Syahputra (2018) that organization needs to conduct an identification to opportunities for self-development of the staffs and ensure that staffs attain sufficient competence to perform their duties optimally. ${ }^{11}$

This study found that the lowest accuracy level of the achievement data was at $72 \%$ and the three data have yet to reach $100 \%$ level. The results of the present study were able to identify weaknesses in the quality management system which shows that managers experience difficulty in managing the data manually, thus resulting in the duplicate data. It is in line with a study found by Ningsih et al (2019) that the development of web-based reporting system is able to identify duplicate data in reporting, so that it can improve the quality of reporting. ${ }^{12}$ Similarly, the results of the study by Rachman (2017) showed that the improvement of quality information services using electronic-based online system is able to generate accurate information and data that can be accounted for. ${ }^{13}$

This study found that assessment of data management and the assessment system are in the yellow category with a score of 2.51 from the total score of 3 , which implies that the data are partially complete/available/performed. RDQA instruments are able to identify weaknesses in the quality management system, thus it can be applied and utilized to assess the quality management system in X Hospital. This is in accordance with the study conducted by Haikal (2019) that the developed RDQA instrument can be used to assess the data quality in order to support the availability of information, decision-making and further improvement measures. ${ }^{14}$

$\mathrm{X}$ Hospital is carrying various missions, including organizes the development of digitization of hospital services, thus they already provide allocation of a sufficient budget. The success of $\mathrm{X}$ 
Hospital in achieving the mission of the hospital is supported by all components of the hospital, including the readiness of human resources. ${ }^{15}$ This is in line with the findings of a study that the staffs are able to receive and manage the system properly when they hold a belief that the system they work on provides benefits in supporting their duties. ${ }^{16}$ Similarly, another study showed that the organization conduct identification to the opportunities of staffs' self-development to perform the duties optimally. ${ }^{11}$

\section{CONCLUSION}

An appropriate data management in quality management is crucial to produce accurate information about the quality improvement. Infrastructure in managing quality needs to be prepared thoroughly, and it requires human resources who are competent and have a high commitment to the quality improvement and patient safety.

The application of RDQA in this study articulated that the systems did not optimally run. System assessment using RDQA instruments was found to be in the yellow category with a score of 2.51 from the total score of 3.0, which indicates that the data are partially complete/available/performed. Therefore, it can be said that implementation of RDQA instrument is needed to analyze the data quality of the quality management system in $\mathrm{X}$ Hospital. Priority areas in the indicator 4 on the process of data management and indicator 5 on the dissemination of the results of the report should be improved. It is also suggested that the hospital management should develop a web-based reporting system, and morning conference needs to be optimized at each level of the quality management system.

\section{FUNDING}

This study is fully funded by the authors.

\section{AUTHOR CONTRIBUTION}

EF as the first researcher who formulated the idea, prepared the research, collected and analyzed the data. FA as the second researcher who prepared and analyzed the data. SPA as the third researcher who edited the report results.

\section{CONFLICT OF INTEREST}

The author declare that they have no conflict of interest.

\section{REFERENCES}

1. The Committee of Hospital Accreditation. Standar Akreditasi Rumah Sakit Jilid I [The Standards of Hospital Accreditation, First Edition]. 2017.

2. Braithwaite J, Clay-Williams R, Taylor N, Ting HP, Winata T, Hogden E, et al. Deepening our understanding of quality in Australia (DUQuA): An overview of a nation-wide, multilevel analysis of relationships between quality management systems and patient factors in 32 hospitals. International Journal for Quality in Health Care. 2020;32(S1):8-21.

3. Committee of Quality and Patient Safety. Pedoman peningkatan mutu RSUP Dr. Kariadi [The guidelines of quality improvement at dr. Kariadi Hospital]. Semarang. 2019.

4. Micah NJ, Luketero SW. Monitoring and evaluation systems and performance of non-governmental based maternal health projects in Bungoma South Sub-County, Kenya. Eur Sci Journal. 2017;13(23):11-38.

5. World Health Organization. Manual on use of Routine Data Quality Audit (RDQA) tool for TB monitoring. [Internet]. World Health Organization. 2010. p. 1-36. Available from: http://whqlibdoc.who.int/ publications/2011/9789241501248 eng.pdf

6. Yusuf M. Metode penelitian kuantitatif, kualitatif dan penelitian gabungan [Quantitative, qualitative and mixed research methods]. Jakarta: Pertama; 2017.

7. Sari NP, Adiputra IM, Sujana E. Pengaruh pemahaman Standar Akutansi Pemerintahan (SAP) dan pemanfaatan sistem informasi akuntansi keuangan daerah terhadap kualitas laporan keuangan pemerintah daerah (Studi kasus pada dinas-dinas di Pemerintah Kabupaten Jembrana) [The influence of understanding on Government Accountancy Standards and the utilization of district financial information system towards the quality of local government financial report]. J Ilmiah Mahasiswa Akutansi Undiksha. 2014;2(1).

8. Sri E, Ali M. Faktor-faktor yang berpengaruh pada akurasi kode diagnosis di Puskesmas Rawat Jalan Kota Malang [Factors influencing diagnosis code accuracy at the Malang City Outpatient Public Health Center]. J Kedokt Brawijaya. 2019;30(3):228-234.

9. Sulastia W, Palampanga A, Yusnita N. Pengaruh kualitas data input, tingkat pemahaman dan tingkat pengawasan terhadap kualitas laporan keuangan (Studi pada SKPD di Kabupaten Tolitoli) [The influence of input data, understanding and monitoring levels towards financial report quality (A study among local stakeholders at Tolitoli District]. e J Katalogis. 2018;6(2):86-97.

10. Rodiah S, Budiono A, Rohman AS. Model diseminasi informasi komunikasi kesehatan masyarakat pedesaan di Kabupaten Bandung Barat [The model of health communication and information dissemination for villagers in West Bandung District]. J Kaji Komun. 2018;6(2):175-190.

11. Syahputra FA. Dampak sistem manajemen kinerja terhadap kinerja karyawan [The impact of performance management on the staff work performance]. 2018;(July):1-7.

12. Ningsih KP, Agushybana F, Sediyono E. The planning of technology-based emergency minimum service standard reporting system. Int J Heal Educ Soc. 2019;2(9):56-65.

13. Rachman ES, Noviyanto B. Pemanfaatan E-Government pada Desa Wonokarto untuk meningkatkan akurasi dan informasi potensi desa [The use of E-Government in Wonokerto Village to increase the accuracy and information of village's potency]. $J$ Technol Accept Model. 2017;8(1):45-50. 
14. Haikal, Martini, Sediyono E. Pengembangan instrumen RDQA untuk surveilans epidemiologi DBD di Dinas Kesehatan Kota Tarakan [RDQA instrument development for dengue epidemiology surveillance at the Tarakan City Health Office]. J Manaj Kesehat Indones. 2019;7(1):16-23.

15. The Ministry of Health of The Republic of Indonesia. Rencana strategis bisnis RSUP Dr Kariadi Semarang [Business strategic plan of the Dr. Kariadi Hospital Semarang]. 2020-2024
16. Widodo AP, Agushybana F, Jati SP. Pengukuran penerimaan sistem informasi EWSKIA berdasarkan persepsi pengguna dengan menggunakan Technology Acceptance Model [Measurement of EWSKIA information system acceptance based on the user's perception by using Technology Acceptance Model]. J Sist Inf Bisnis. 2018;8(2):166-173.

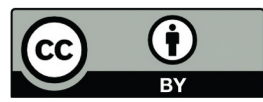

This work is licensed under a Creative Commons Attribution 